\title{
Nutritive Value and the Quality of Ensiled Napier Grass (Pennisetum Purpureum Schum.) and Banana (Musa Acuminata) Peelings
}

\author{
Sangle Yohanes Randa, Marlyn Nelce Lekitoo, Deny Anjelus lyai and Freddy Pattiselanno* \\ Faculty of Animal Science University of Papua, \\ Kampus UNIPA JI. Gunung Salju Amban Manokwari, 98314 Papua Barat \\ *Corresponding author email: f.pattiselanno@unipa.ac.id
}

\begin{abstract}
This paper aimed to evaluate the nutritive value and the quality of ensiled Napier grass (Pennisetum purpureum Schum) and banana (Musa acuminate) peelings. Different levels of banana peeling and Napier grass used in this study were as follows: $100 \%$ Napier Grass (NG), $75 \% \mathrm{NG}+25 \%$ Banana Peeling (BP), $50 \% \mathrm{NG}+$ $50 \% \mathrm{BP}, 25 \% \mathrm{NG}+75 \% \mathrm{BP}$ and $100 \% \mathrm{BP}$. Napier grass and banana peeling were mixed, weighed and placed into empty jam bottle with weights ranging from 64.4 grams to 509.2 grams as a simulated laboratory silo. Physically, the color of silage were light yellow with a little greenish color for $100 \%$ napier grass, light to moderately yellow for the three combinations of napier and banana peel and yellow for $100 \%$ banana peel. Texture ranged from dry and coarse for napier grass, relatively dry for the combinations and moderately wet for the banana peel. The napier grass had a slightly acidic smell, the combinations had slightly sweet, acidic smell while the $100 \%$ banana peel had a sweeter, acidic smell. Likewise, $\mathrm{pH}$ before ensiling had ranged from $5.7(25 \% \mathrm{NG}+75 \% \mathrm{BP})$ to $7.5(100 \% \mathrm{BP})$ while after ensiling the $\mathrm{pH}$ changed from 4.575 (100\% napier grass) to 5.75 (100\% banana peel). There were significant differences on DM, Moisture, CP, EE, CF, and Ash before ensiling. Similar trend was observed after ensiling except the ash content of all the treatments. ADF and NDF did not show significant variations in all treatments. IVDMD and IVOMD before ensiling varied significantly, but after ensiling only IVDMD of the treatments differed significantly. In terms of physical attributes, nutritive value and digestibility, banana peel can be used as silage material. All treatments generated comparable acceptability when fed to the animal.
\end{abstract}

Key words: Napier grass, banana peelings, silage, quality

Abstrak. Tulisan ini bertujuan untuk mengevaluasi nilai gizi dan kualitas silase rumput gajah (Pennisetum purpureum Schum) dan kulit pisang (Musa acuminata). Perbandingan rumput gajah dan kulit pisang yang digunakan dalam penelitian ini bervariasi: Rumput Gajah 100\% (RG), $75 \%$ (RG) + 25\% Kulit Pisag (KP), 50\% RG + $50 \% \mathrm{KP}, 25 \% \mathrm{RG}+75 \% \mathrm{KP}$ dan 100\% KP. Rumput gajah dan kulit pisang dicampur berdasarkan kombinasi persentase perlakuan, ditimbang dan dimasukkan ke dalam botol selai kosong dengan berat mulai dari 64,4 gram sampai 509,2 gram sebagai laboratorium simulasi silo. Secara fisik, silase berwarna kuning muda dan sedikit kehijauan untuk rumput gajah $100 \%$, ringan sampai agak kuning untuk tiga kombinasi rumput gajah dan kulit pisang dan kuning untuk kulit pisang $100 \%$. Tekstur berkisar dari kering dan kasar untuk rumput gajah, relatif kering untuk kombinasi rumput gajah dan kulit pisang dan cukup basah untuk kulit pisang. Rumput gajah memiliki aroma yang sedikit asam, kombinasi rumput gajah dan kulit pisang sedikit manis dan berbau asam, sementara kulit pisang berbau manis dan asam. Demikian pula, $\mathrm{pH}$ sebelum proses silase berkisar antara 5,7 (25\% RG + 75\% KP) sampai 7,5 (100\% KP) sedangkan setelah proses silase, pH berubah dari 4,575 (100\% RG) menjadi 5,75 (100\% KP). Ada perbedaan yang signifikan pada Bahan Kering, Kelembaban, Protein Kasar, Ekstrak Ether, Serat Kasar, dan Abu sebelum proses silase. Kecenderungan serupa diamati setelah proses silase kecuali kandungan abu dari semua perlakuan. ADF dan NDF tidak menunjukkan variasi yang signifikan dalam semua perlakuan. IVDMD dan IVOMD sebelum proses silase bervariasi secara signifikan, namun setelah proses silasi, hanya perlakuan IVDMD yang berbeda secara signifikan. Berdasarkan atribut fisik, nilai gizi dan kecernaan, kulit pisang bisa digunakan sebagai bahan silase. Semua perlakuan sama dikonsumsi saat diberikan pada ternak.

Kata kunci: Rumput gajah, kulit pisang, silase, kualitas 


\section{Introduction}

Silage can be made from many different crops and may be a more manageable product than hay. Silage is naturally preserved by lactic acid fermentation of sugars by bacteria after the forage has been wilted and stored to exclude air. The main goal of silage making is to preserve as much of the nutritional value of the original crop as possible. The objective of silage preservation is conversion of moist, chopped forage with a short storage life to preserved silage that can be fed to livestock as needed. Yokota et al., (1994) stated that silage making is a method of forage preservation for animal production. According to Yokota et al., (1994) silage from a number of tropical herbage plants was stable against anaerobic decomposition, but its chemical characteristics were different from lactate-type silages of temperate forage.

Tropical grass biomass increases with maturity, but decreases in nutritive value. To overcome this problem these grasses are frequently ensiled at an early growing stage. However, young plants have a high moisture content, high buffering capacity and a low-level of soluble carbohydrates. Woolford (1984) explained that these factors have a negative influence on the fermentation process, preventing a rapid lowering of the $\mathrm{pH}$ and thus allowing unwanted secondary fermentation, consequently damaging the quality of the final product.

Banana is a large herbaceous plant and the fruit is a berry and protected by a cover known as peel. Banana peelings are abundant as waste materials that create negative impact to the environment if not properly disposed (Sabutan, 1996). Trunk, leaf and peelings are usually used for animal feed (Karto, 1995). Banana peelings are also used in various food and non-food applications serving as thickening agent, coloring and flavor, alternative source for macro and micronutrients, nutraceuticals, natural fibers, and sources of natural bioactive compounds and biofertilizers (Padam et al., 2014). In terms of pharmacological relevance, banana peel is known by its local and traditional use to promote wound healing mainly from burns and to help overcome or prevent a substantial number of illnesses, as depression (Paraeira \& Maraschin, 2015).

Subramanian et al., (1998) reported that banana peel rich in polysaccharides thus they could be easily digested. Forty percent of fresh banana peel mixed with $10 \%$ of King Grass increased a body weight of PO cows (Wina, 2001). A solution to provide feed for animals by utilizing banana peelings through the silage making is important to reduce the environmental problems. It was considered as agricultural waste which almost all of the banana's parts could be used ad animal feed.

Silage additives include feedstuffs, urea, ammonia, inoculants and acids are available used for different reasons. Additives are used to improve nutrient composition of silage, to reduce storage losses by promoting rapid fermentation, to reduce fermentation losses by limiting extent of fermentation, and to improve bunk life of silage (increase aerobic stability). In other words, the reason for applying an additive was to prevent secondary fermentation and butyric acid silage.

Bolsen et al., (1996), categorized silage additives into fermentation inhibitors, fermentation stimulants and substrate or nutrient sources. Molasses, which included in substrate sources, has been used as a silage additive for many years. Molasses, unlike grain, provides fermentable carbohydrate; therefore, molasses addition can improve the fermentation of some hay crop forages. Other research also found that the applying of molasses improved fermentative 
quality, feed intake and digestibility of Napier grass (Bureenok et al., 2012).

There is an opinion that Napier grass ensiled without the additive was low in lactic acid and high in $\mathrm{pH}$ value, ammonia, nitrogen and VFA (Yokota et al., 1996). In summer session, fermentation quality of Napier grass was improved by the input of additives with the highest quality in lactic acid bacteria and Acremonium cellulose $(\mathrm{LAB}+\mathrm{AC}$ ) resulting in low $\mathrm{pH}$ and sum of the butyric, caproic and valeric acid (Fukugawa et al., 2016). It was also proved that the ensiling quality structural and nonstructural carbohydrate and enzymatic digestibility (ED) value of mature Napier grass silage improved through additives (Desta et al., 2016).

Assuming that the above problems are the main limitations to the ensilage of Napier grass, research was undertaken with the objective to find practical solutions to enable the production of good quality silage from the Napier grass. The experiment was designed to test the hypothesis and to evaluate the effects of banana peeling as of sugar sources that could replace the function of molasses which can increases the fermentable sugar content in silage. This study also wanted to probe at what level banana peeling will take the function of molasses as sugar source.

The study was conducted to evaluate the use of banana peeling as a feed material along with Napier grass in silage form, and particularly aimed to: (1) evaluate the physical characteristics of the different levels of banana peeling and Napier grass in silage form; (2) identify the nutritive value of the different levels of banana peeling and Napier grass in fresh and silage forms, and (3) measure the $\mathrm{pH}, \mathrm{ADF}, \mathrm{NDF}, \mathrm{IVDMD}$ and IVOMD of the different levels of banana peeling and Napier grass in fresh and silage forms.

\section{Materials and Methods}

\section{Ensiling Material}

The study is carried out to produce silages by using banana peelings and Napier grass as forage materials. An approximately two-months-old Napier grass (Pennisetum purpureum Schum.) from Dairy Training and Research Institute (DTRI) pasture at Los Baños, and fresh, ripe banana peelings from banana cue vendors at San Pablo were used as the materials of silage.

\section{Treatments}

Different levels of banana peeling and Napier grass were used in this study. The levels of Napier grass and banana peeling compared as treatments with four replications were as follows: 100\% Napier Grass (NG), 75\% (NG) + 25\% Banana Peeling (BP), 50\%NG + 50\%BP, 25\%NG + 75\% BP and $100 \% \mathrm{BP}$.

\section{Ensiling procedure}

The forage materials were chopped into about $2 \mathrm{~cm}$ lengths. After chopping, Napier grass and banana peeling were mixed based on the percentage combination as treatments, weighed and placed into empty jam bottle with weights ranging from 64.4 grams to 509.2 grams as a simulated laboratory silo. All bottle silos were properly packed with the forage materials and closed as airtight as possible, sealed with masking tape. Samples were stored in eight weeks at the DTRI Forage Laboratory.

\section{Physical and chemical analyses}

Samples were taken at the time of silo filling and after ensiling and subjected to physical and proximate analyses. Physical evaluation of the ensiled materials after about $1 \frac{1}{2}$ months was made to characterize the smell/odor, texture, color and percent spoilage Samples in different weights were oven and sun-dried to determine the dry matter and moisture contents. 
The remaining ensiled samples from each treatment were dried at $70^{\circ} \mathrm{C}$ up to constant dry weight. Dried samples were ground 40 mesh and subsequently analyzed for dry matter, ash, crude protein (CP), crude fiber (CF) following the AOAC (2005). Silage $\mathrm{pH}$ was measured using a digital $\mathrm{pH}$ meter. Concentration of neutral detergent fiber (NDF) was determined according to Van Soest and Wine (1967). Acid detergent fiber (ADF) was analyzed using Van Soest (1963). In vitro dry matter and organic matter digestibility were determined following the procedure of Tilley and Terry (1963).

Proximate analyses were done at Animal Nutrition Laboratory Institute of Animal Science while ADF, NDF, IVDMD, and IVOMD were done at the Animal Nutrition Division Laboratory at Dairy Training and Research Institute, UP Los Baños.

\section{Statistical Analyses}

Results of the physical and chemical analysis of dry matter (DM), crude protein (CP), crude fiber (CF), ash, in vitro dry matter digestibility (IVOMD) of the ensiled forage materials were statistically analyzed using a one way classification analyses of variance (ANOVA) in a completely randomized design (CRD) with five (5) treatments and four (4) replications.

The same statistical tool was used in comparing differences the results of proximate, IVDMD, IVOMD, pH and percent spoilage analyses of the un-ensiled materials. Comparison among treatment means was done using the Duncan's Multiple Range Test (DMRT). Descriptive comparison was used in comparing $\mathrm{pH}, \mathrm{ADF}$ and NDF for the fresh materials.

\section{Results and Discussion}

Table 1 shows the physical evaluation of the different levels of combination between Napier grass and banana peeling. In terms of color, the
$100 \%$ banana peeling had a yellowish color, relatively wet in texture and a sweet, slightly acidic smell. The $100 \%$ Napier grass on the other hand, had a light, little bit greenish in color, relatively dry and coarse in texture and had slightly acidic smell.

The combinations in varying levels of the banana peeling and Napier grass had light colors, relatively dry and coarse texture and range between slightly and moderately sweet smell. The physical performance of the silage indicated that increase in banana peeling percentage lead to the yellow color, wetter and sweeter smell of the silage. It was also observed that all levels of the silage were readily taken when fed to cattle in DTRI, UPLB.

The average spoilage of the ensiled Napier grass and banana peeling as well as both combinations at different levels are shown in Table 2; the moisture content of different treatments are presented in Table 3. Differences in the percent spoilage of the $100 \%$ Napier grass and $100 \%$ banana peeling with that spoilage of their combinations were not significant. Results showed less spoilage in the $50 \%$ NG $+50 \%$ BP treatment. For other treatments, spoilage was attributed to broken covers of the used laboratory silos.

The moisture contents among the combinations were significantly different. Apparently, moisture content was higher when levels of banana peel were greater in the silage. This can be attributed to the high moisture content of banana peeling.

In general, the moisture content of the silage should be below 70 percent for bunker or trench silos, below 50 percent for gas-limiting silos, and approximately 60 percent for upright (tower) silos and silage bags (Grant and Stock, 1996). If the moisture content of the forage is too high, effluent will flow from the silage mass. 
According to Uchida et al., (1989) ensiling crop with high moisture content usually lead to clostridia fermentation, low DM voluntary intake, and large volume of effluent with highly digestible nutrients. Much effort, therefore have been devoted to improve silage quality and feeding value by controlling moisture content prior to ensiling.
The $\mathrm{pH}$ of different levels of Napier grass and banana peel combinations before ensiling ranged between 5.7 and 7.5 (Table 4). The 100\% banana peel silage had a higher $\mathrm{pH}$ value while the $75 \%$ $\mathrm{NG}+25 \%$ banana peel had the lower $\mathrm{pH}$ value.

Table 1. Physical evaluation of ensiled Napier grass and Banana peelings

\begin{tabular}{llll}
\hline Silage & Color & Texture & Smell \\
\hline $100 \%$ NG & Light yellow, a little bit & Relatively dry and & Slightly acidic \\
& greenish & coarse \\
$75 \%$ NG $+25 \%$ BP & Light yellow & $\begin{array}{l}\text { Relatively dry and } \\
\text { coarse }\end{array}$ & Slightly sweet smell \\
$50 \%$ NG $+50 \%$ BP & Light yellow & $\begin{array}{l}\text { Relatively dry and } \\
\text { coarse }\end{array}$ & Moderately sweet smell \\
$25 \%$ NG $+75 \%$ BP & Moderately yellow & Less dry & Moderately sweet smell \\
$100 \%$ BP & Yellowish & Relatively wet & Sweeter smell, slightly acidic \\
\hline
\end{tabular}

Table 2. Average \% spoilage of ensiled Napier grass and Banana peelings

\begin{tabular}{lc}
\hline Silage treatments & \% Spoilage ${ }^{\mathrm{ns}}$ \\
\hline $100 \%$ Napier Grass & 14.54 \\
$75 \%$ Napier Grass + 25\% Banana Peelings & 24.45 \\
$50 \%$ Napier Grass + 50\% Banana Peelings & 13.02 \\
$25 \%$ Napier Grass + 75\% Banana Peelings & 11.78 \\
$100 \%$ Banana Peelings & 7.95 \\
\hline
\end{tabular}

${ }^{\text {ns }}$ Not significant ( $\left.P>0.05\right)$

Table 3. Moisture content of the different silage treatments

\begin{tabular}{lc}
\hline Silage treatments & \% Moisture Content $\left.{ }^{*}\right)$ \\
\hline $100 \%$ Napier Grass & $82.43^{\text {cd }}$ \\
$75 \%$ Napier Grass + 25\% Banana Peelings & $80.47^{\mathrm{d}}$ \\
$50 \%$ Napier Grass + 50\% Banana Peelings & $83.91^{\mathrm{bc}}$ \\
$25 \%$ Napier Grass + 75\% Banana Peelings & $85.67^{\mathrm{ab}}$ \\
$100 \%$ Banana Peelings & $87.32^{\mathrm{a}}$ \\
\hline
\end{tabular}

$\left.{ }^{*}\right)$ Means with same superscripts are not significantly different $(\mathrm{P}<0.05)$

Table 4. Average $\mathrm{pH}$ of different treatment before and after ensiled

\begin{tabular}{lcc}
\hline Silage Treatments & Before $^{\text {ns }}$ & After $^{*}$ ) \\
\hline $100 \%$ Napier Grass & 6.1 & $4.575^{\mathrm{b}}$ \\
$75 \%$ Napier Grass + 25\% Banana Peelings & 5.7 & $4.625^{\mathrm{b}}$ \\
$50 \%$ Napier Grass + 50\% Banana Peelings & 6.0 & $4.9^{\mathrm{b}}$ \\
$25 \%$ Napier Grass + 75\% Banana Peelings & 6.95 & $4.775^{\mathrm{b}}$ \\
$100 \%$ Banana Peelings & 7.5 & $5.75^{\mathrm{a}}$ \\
\hline
\end{tabular}

ns) Not siginificant ( $P>0.05$ )

${ }^{*}$ Same superscript values are not significantly different $(P<0.01)$ 
Similar trend was observed on the obtained $\mathrm{pH}$ value after ensiling except that the 100\% Napier grass had the lowest $\mathrm{pH}$ value. The silage $\mathrm{pH}$ in this study was slightly different compared to the study of Yokota (1994) whom used Napier grass in different time of harvesting added by $4 \%$ molasses, which ranged between 4.03 and 4.29. The $\mathrm{pH}$ value of napier grass silage was influenced by additive treatments. Characteristics of napier grass silage after 21 fermentations using different percentage of inoculant and crude enzymes from Trichoderma reesei ranged between 3.53 and 3.62 (Nurjana et al., 2016).

The $100 \%$ banana peel silage had a higher $\mathrm{pH}$ (already alkaline) than that of the other silages, which in turn did not show significant differences on their $\mathrm{pH}$ values. This higher $\mathrm{pH}$ value of $100 \%$ banana peel can be attributed to its higher protein content and it also influenced the buffering capacity of banana peelings. According to Weiss and Underwood (2001) hay crops, on the other hand, have a high buffering capacity due to high protein and mineral content and relatively low concentrations of fermentable carbohydrates. Therefore, $\mathrm{pH}$ drop in hay crop silage is slow and final $\mathrm{pH}$ is comparatively high (approximately 4-4.5). However, Napier grass ensiled without the additive was low in lactic acid and high in $\mathrm{pH}$ value, ammonia nitrogen and VFA (Yokota et al., 1994).

Similar to the Ammonia $\mathrm{N}$ content of the silage, the $\mathrm{pH}$ will give a good indication of whether silage has a good fermentation and is likely to store satisfactorily. The desirable $\mathrm{pH}$ range for clamp silage is $3.8-4.2$. Above $\mathrm{pH}$ 4.5, the risk of deterioration in store becomes increasingly apparent. However, high dry matter silage can be satisfactory at a higher $\mathrm{pH}$, but values at 3.6 and below are very acidic (Kim et al., 2001).

Banana peel had relatively high nutritive value than Napier grass in terms of its Crude Protein,
Crude Fat, NFE and ash (Table 5). The high nutritive value are supported the higher $\mathrm{pH}$ value of banana peeling than Napier grass. Before ensiling, we assumed banana peelings have significant different of sugar content than Napier grass, but the analyses showed that the sugar content (NFE) of both silage materials are really similar. We then therefore surmised this situation is due to the mixing of green and ripe banana peeling we use as a treatment.

Compared to the study of Sabutan (1996), CP, $\mathrm{CF}, \mathrm{EE}$ and $\mathrm{DM}$ of banana peel are almost similar. However, ash and NFE value in Sabutan's study are higher than our findings. Difference results between two these studies may due to the different variety of banana used in both studies. The CP and CF of banana peel in this study were in the range of $\mathrm{CP}$ and $\mathrm{CF}$ values from the study by Karto (1995) $6.5-9.5$ and 15.32 - 26.7. The nutrient composition of the napier grass in this study was lower compared to the study of Nurjana et al. (2016): CP 6.51\%; EE 1.35\% except for CF $29.51 \%$ - all in DM basis.

DM value of Napier grass was higher than banana peel. The $\mathrm{CP}$ and ash contents of the used banana peel were similar, but DM and crude fiber were higher in the used samples. Likewise, ether extract was also lower than the EE obtained by Sabutan (1996). The CP and ADF contents of the used Napier grass were lower than what were obtained by Del Barrio et al. (1998). Nutritive values of fresh Banana peel, Napier grass and their combinations in fresh and ensiled forms are shown in Table 6.

The ensiled DM, CP, CF and EE of the five treatments were different, that also observed in the fresh form. DM value of silage using molasses as additive was significantly high is in line with the observed lower NDF content of this silage (Bureenok et al., 2012). The $100 \%$ banana peel had a higher moisture, crude fat, and NFE, but had the lowest DM and ash values. 
ISSN 1411-2027

Table 5. Nutritive value of Napier grass and Banana peelings

\begin{tabular}{lllcccc}
\hline \multirow{2}{*}{ Forage } & Dry Matter & CP & EE & CF & Ash & NFE \\
\cline { 2 - 7 } & (Fresh Basis) & & \multicolumn{3}{c}{ (Dry Matter Basis) } \\
\hline Napier & 97.68 & 5.96 & 1.28 & 33.92 & 14.68 & 43.87 \\
Banana Peel & 90.50 & 7.60 & 9.27 & 16.64 & 12.20 & 46.26 \\
\hline
\end{tabular}

Table 6. Nutritive value ${ }^{*}$ of fresh and ensiled Napier grass and Banana peeling*include crude fat

\begin{tabular}{|c|c|c|c|c|c|c|c|c|c|c|}
\hline \multirow[b]{2}{*}{ Treatment } & \multicolumn{5}{|c|}{ Fresh (Dry Matter Basis) } & \multicolumn{5}{|c|}{ Ensiled (Dry Matter Basis) } \\
\hline & DM & $\mathrm{CP}$ & $\mathrm{EE}$ & $\mathrm{CF}$ & $\mathrm{ASH}$ & DM & $\mathrm{CP}$ & $\mathrm{EE}$ & $\mathrm{CF}$ & ASH \\
\hline $100 \% \mathrm{NP}$ & $97.68^{a b}$ & $5.99^{d}$ & $1.28^{\mathrm{c}}$ & $34.68^{a}$ & $12.55^{b}$ & $95.42^{a}$ & $5.96^{b c}$ & $2.34^{\mathrm{d}}$ & $33.92^{a}$ & 14.68 \\
\hline $75 \% N G+25 \% B P$ & $97.66^{\mathrm{ab}}$ & $10.17^{a}$ & $4.85^{b}$ & $25.23^{b}$ & $15.09^{a}$ & $94.94^{\mathrm{a}}$ & $5.13^{d}$ & $2.31^{d}$ & $32.7^{\mathrm{a}}$ & 14.56 \\
\hline $50 \% N G+50 \% B P$ & $95.9^{b}$ & $7.08^{\mathrm{ab}}$ & $5.60^{b}$ & $23.97^{d}$ & $14.88^{\mathrm{a}}$ & $92.91^{\mathrm{ab}}$ & $6.83^{\mathrm{ab}}$ & $4.08^{c}$ & $27.24^{b}$ & 14.64 \\
\hline $25 \% N G+75 \%$ BP & $97.79^{a}$ & $9.21^{\mathrm{ab}}$ & $6.81^{b}$ & $16.63^{c}$ & $14.6 b^{a}$ & $92.29^{\mathrm{ab}}$ & $7.8^{\mathrm{a}}$ & $5.64^{b}$ & $23.95^{c}$ & 14.54 \\
\hline $100 \% \mathrm{BP}$ & $90.5^{c}$ & $7.94^{c}$ & $9.27^{\mathrm{a}}$ & $13.71^{c}$ & $13.36^{b}$ & $90.11^{\mathrm{b}}$ & $7.6^{\mathrm{ab}}$ & $8.89^{a}$ & $16.64^{d}$ & 12.2 \\
\hline
\end{tabular}

*) Means in the same column with the same letter are not significantly different $(P>0.01)$

The $75 \%$ BP $+25 \%$ NG had the highest CP content among the treatments, but had similar nutritive values with the other treatments except $100 \%$ banana peel. Ash content in all of the fresh treatments was significantly different, though it was not similar but did not differ significantly after ensiling.

NFE content of the treatments were not different in fresh form, but differed significantly after ensiling with the $100 \%$ banana peel had higher NFE. It is however noted that nutrient contents in the ensiled form were lower than in fresh form. According to Widjastuti and Hernawan (2012), the use of fresh banana peel up to $20 \%$ in the ration of broiler suffering from heat stress can still support the good results in the final broiler weight, percentage of carcass and percentage of abdominal fat within normal limits.
DM digestibility of silage using molasses as additive was significantly high is in line with the observed lower NDF content of this silage

IVDMD and IVOMD values before and after ensiling differed significantly (Table 7). IVDMD values of $100 \%$ banana peeling before and ensiling were consistently higher than the $100 \%$ Napier grass and their combinations. Different trend was observed in the IVOMD value obtained before ensiling where the $100 \%$ Napier grass was higher than the other treatments.

After ensiling however, the $100 \%$ banana peel had a higher IVOMD value than the other treatments although differences were not significant. The IVDMD values of fresh Napier grass were similar to the values obtained by Del Barrio et al. (1998) in both local and hybrid varieties during dry, dry-hot, dry-cold climate.

Table 7. In vitro dry matter digestibility and in vitro organic matter digestibility of Napier grass and Banana peeling before and after ensilage

\begin{tabular}{lcccc}
\hline Treatment & \multicolumn{2}{c}{ IVDMD (\% / DM) } & \multicolumn{2}{c}{ IVOMD (\% / DM) } \\
\cline { 2 - 5 } & Before & After & Before & After \\
\hline $100 \%$ NG & $44.00^{\mathrm{b}}$ & $42.23^{\mathrm{d}}$ & $90.39^{\mathrm{ab}}$ & $79.47^{\mathrm{ns}}$ \\
$75 \% \mathrm{NG}+25 \%$ BP & $45.01^{\mathrm{a}}$ & $44.74^{\mathrm{d}}$ & $88.52^{\mathrm{ab}}$ & 74.07 \\
$50 \%$ NG + 50\% BP & $47.81^{\mathrm{a}}$ & $50.67^{\mathrm{bc}}$ & $84.81^{\mathrm{b}}$ & 79.23 \\
$25 \%$ NG + 75\% BP & $47.06^{\mathrm{a}}$ & $53.60^{\mathrm{ab}}$ & $94.33^{\mathrm{a}}$ & 85.87 \\
$100 \%$ BP & $51.84 \mathrm{a}$ & $56.41^{\mathrm{a}}$ & $83.94^{\mathrm{b}}$ & 80.44 \\
\hline
\end{tabular}


Dry matter and organic matter digestibility determined by in vitro technique showed and IVDMD and IVOMD of $42.23 \%$ and $79.47 \%$ respectively for napier. Our finding is lower for IVDMD and higher for IVOMD compared to the results of Yokota et al. (1994) that ranged from $49.4 \%$ to $69.2 \%$ for IVDMD and $48.6 \%$ to $71.9 \%$ for IVOMD.

Results we obtained in this study obviously showed the difference between the IVDMD and IVOMD values of our treatment after ensiling. It maybe because IVOMD analysis is not include lignin component analysis, however IVDMD analysis covered all component materials include lignin. ADF and NDF contents of the treatments are shown in Table 8. Along with the tendency of increasing in NDF contents after ensiled, evidently showed that our treatments have high fiber content, and it will decrease the digestibility. Differently, the NDF content of Napier grass was clearly affected by the fermentation with the addition of molasses and cassava meal (non-fiber sources) lowered the content of NDF compared to untreated and fermented juice of epiphytic lactic acid bacteria - FLJB silages (Bureenok et al., 2012). Yokota et al. (1994) reported that lignin is a chemical component in forage cell walls, increases with the development of the grass and is most associated with reduced digestibility of fiber.
Differences in ADF and NDF contents of the treatments after ensiling were not significant, however, the NDF content of the treatments had increased after ensiling. In contrast, ADF of the treatments did not follow the same consistent trend after ensiling.

\section{Conclusions}

Physically, the color of silage were light yellow with a little greenish color for $100 \%$ napier grass, light to moderately yellow for the three combinations of napier and banana peel and yellow for $100 \%$ banana peel. Texture ranged from dry and coarse for napier grass, relatively dry for the combinations and moderately wet for the banana peel. The napier grass had a slightly acidic smell, the combinations had slightly sweet, acidic smell while the $100 \%$ banana peel had a sweeter, acidic smell. Likewise, $\mathrm{pH}$ before ensiling had ranged from 5.7 ( $25 \% \mathrm{NG}+75 \% \mathrm{BP})$ to 7.5 (100\% BP) while after ensiling the $\mathrm{pH}$ changed from 4.575 (100\% napier grass) to 5.75 (100\% banana peel).

There were significant differences on DM, Moisture, $\mathrm{CP}, \mathrm{EE}, \mathrm{CF}$, and Ash before ensiling. Similar trend was observed after ensiling except the ash content of all the treatments. ADF and NDF did not show significant variations in all treatments. IVDMD before ensiling varied

Table 8. Average ADF and NDF of different treatment before and after ensiled

\begin{tabular}{lcccc}
\hline Silage Treatments & \multicolumn{2}{c}{ Before } & \multicolumn{2}{c}{ After } \\
\cline { 2 - 5 } & ADF & NDF & ADF & NDF \\
\hline $100 \%$ Napier Grass (NG) & 24.00 & 68.06 & 38.34 & 74.23 \\
$75 \%$ NG + 25\% BP & 27.56 & 68.82 & 26.27 & 64.40 \\
$50 \%$ NG + 50\% BP & 30.94 & 80.24 & 26.54 & 63.69 \\
$25 \%$ NG + 75\% BP & 23.27 & 57.37 & 32.12 & 63.05 \\
100 Banana Peelings (BP) & 32.84 & 42.54 & 26.37 & 64.17 \\
\hline
\end{tabular}


significantly, but after ensiling only IVDMD of the treatments differed significantly.

In terms of physical attributes, nutritive value and digestibility, banana peel can be used as silage material. All treatments generated comparable acceptability when fed to the animal. It is suggested that further study, specifically in vivo trial, will be conducted to validate the feeding and nutritional value of banana peel as alternative silage for ruminants.

\section{Acknowledgement}

The researchers express their heartfelt gratitude to all individuals who in one way or another made the conduct of the study possible. This study has been possible with the assistance of Dr. Ulysses M. Lustria for his wholehearted guidance, Dr. Edwin S. Luis and his staff for their unselfish support during the proximate analysis. We appreciated all staff of DTRI Nutrition Laboratory for their guidance and support in the conduct of silage making, $\mathrm{pH}, \mathrm{ADF}, \mathrm{NDF}, \mathrm{IVDMD}$ and IVOMD analyses.

\section{References}

AOAC (Association of Official Analytical Chemist). 2005. Official Methods of Analysis of the Association of Official Analytical Chemist. Benjamin Franklin Station. Washington.

Bolsen KK, G Ashbell, and ZG Weinberg. 1996. Silage fermentation and silage additives. A review. AsianAus. J. Anim. Sci. 9(5):483-493.

Bureenok S, C Yuangklang, K Vasupen, JT Schonewille, and Y Kawamoto. 2012. Asian-Aust. J. Anim. Sci. 25(9):1248-1254.

doi: http://dx.doi.org/10.5713/ajas.2012.12081.

Del Barrio A, BA Oliveros, RM Lapitan, and TS Lihat. 1998. Yield, chemical composition and In-vitro Dry Matter Digestibility of different forage grasses. Phil. J. of Vet. \& Animal Science. 24(384):79-87.

Desta ST, XJ Yuan, J Li, and T Shao. 2016. Ensiling characteristics, structural and non-structural carbohydrate composition and enzymatic digestibility of Napier grass ensiled with additives. Bioresource Technology 221, 447-454. http://doi.org/10.1016/j.biortech.2016.09.068.

Fukugawa S, Y Ishii, and I Hattori. 2016. Fermentation quality of round-bale silage as affected by additives and ensiling seasons in Dwarf Napiergrass (Pennisetum purpureum Schumach). Agronomy 6, 48:1-10. doi:10.3390/agronomy6040048.

Grant R and R Stock. 1996. Harvesting and preserving hay crop silage. http://www.ianr.unl. edu/pubs/ range/g142.html.

Karto AA. 1995. Penggunaan kulit pisang sebagai pakan sapi PO. Prosiding Sain dan Teknologi Peternakan Balai Penelitian Ternak p. 126-131.

Kim JG, ES Chung, S Seo, JS Ham, WS Kang, and DA Kim. 2001. Effects of Maturity at Harvest and Wilting Days on Quality of Round Baled Rye Silage. AsianAust. J. Anim. Sci. 14(9): 1233-1237. doi: https://doi.org/10.5713/ajas.2001.1233.

Nurjana DJ, S Suharti, and Suryahadi. 2016. Improvement of Napier Grass silage nutritive value by using inoculant and crude enzymes from Trichoderma reesei and its effect on in-vitro rumen fermentation. Media Peternakan 39(1): 46-52, doi: 10.5398/medpet.2016.39.1.46.

Padam BS, HS Tin, and FY Chye. 2014. Banana byproducts: an under-utilized renewable food biomass with great potential. J Food Sci Technol 51: 3527. doi:10.1007/s13197-012-0861-2.

Pareira A and M Maraschin. 2015. Banana (Musa spp) from peel to pulp: Ethnopharmacology, source of bioactive compounds and its relevance for human health. Journal of Ethnopharmacology 160: 149163, http://doi.org/10.1016/j.jep.2014.11.008.

Sabutan MG. 1996. Banana (Musa paradisiaca sapientum) fruit peeling meal increased weight gain on Cobb broilers. Journal of Animal Husbandry and Agriculture: 26-29.

Subramanian PR, R Kadirvel, K Viswanathan and D Candrasekaran.1998. In vitro studies and short-term feeding trial in lambs to evaluate plantain sheath (Musa sapientum) as a feed for ruminants. Anim. Feed Sci. Tech. 20: 343-348.

Uchida S. KH Kim, and IS Yun. 1989. The effect of wilting on silage making from the viewpoint in 
connection with Monsoon Asia. A review. AsianAus. J. Anim 2 (1):43-49.

Van Soest PJ. 1963. Use of detergents in the analysis of fibrous feeds. II. A rapid method for the determination of fiber and lignin. J.A.O.A.C. 50:5055.

Van Soest PJ and RH Wine. 1967. Use of detergents in the analysis of fibrous feeds. IX. Determination of plant cell-wall constituents. J.A.O.A.C. 50:50-55.

Weiss B and J Underwood. 2001. Silage additives In: (http://www.ohioline.osu.edu/agr-fact/0018.html).

Widjastuti T and E Hernawan. 2012. Utilizing of banana peel (Musa sapientum) in the ration and its influence on final body weight, percentage of carcass and abdominal fat on broilers under heat stress condition. Zootehnie 57, 104-109.

Wina E. 2001. Tanaman pisang sebagai pakan ternak. Wartazoa 11(2): 20-27.

Woolford MK. 1984. The Silage Fermentation., Marcel Dekker, Inc., New York, NY.

Yokota H. T Okajima, and M Ohshima. 1994. Effect of harvest intervals on the chemical composition and nutritive value of napier grass (Pennisetum purpureum Schum) silages for goats. Asian-Aus. J. Anim

7

(4):

591-596. 